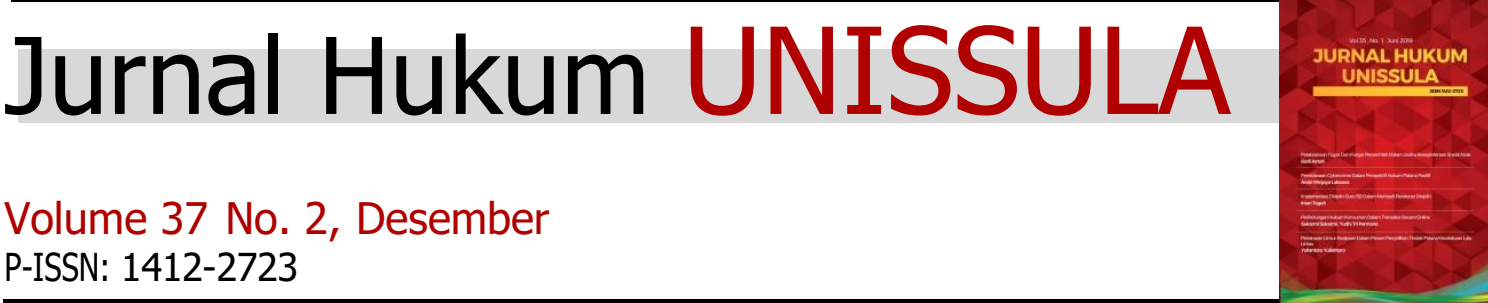

\section{PERLINDUNGAN HUKUM TERHADAP KREDITUR AKIBAT SURAT KUASA MEMBEBANKAN HAK TANGGUNGAN YANG TERDEGRADASI SEBAGAI AKTA DI BAWAH TANGAN}

\section{Gusriadi}

Fakultas Hukum Universitas Gadjah Mada, E-mail: gusriadi@mail.ugm.ac.id

\section{Taufiq El Rahman}

Fakultas Hukum Universitas Gadjah Mada. E-mail: taufiqelrahman ti10@mail.ugm.ac.id

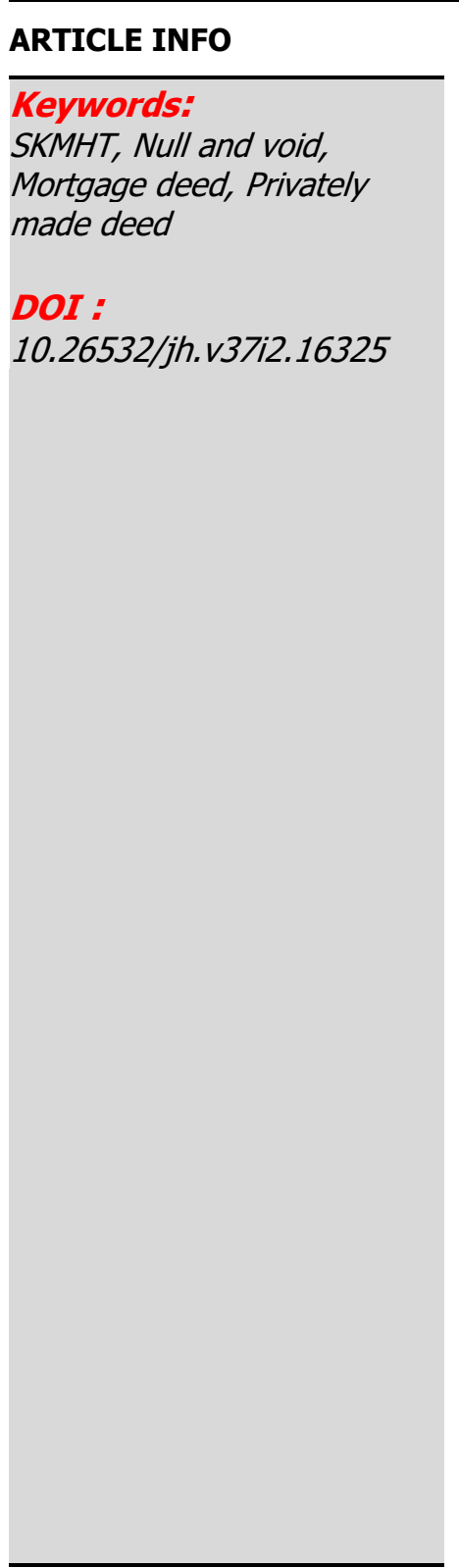

\section{ABSTRACT}

This study has two (2) objectives, first to analyze the legal consequences of the Power of Attorney to Charge for the Right of Land Mortgage (SKMHT) which has been relegated into privately made deed and used as a requirement to create a Mortgage Deed (APHT) that was registered to National Land Authority of Bantul Regency. The second objective is to analyze the legal protection of creditor against SKMHT which has been relegated into privately made deed. As a result, that APHT made based on SKMHT was not issue as a violation of the subjective and objective conditions for the validity of the agreement and the principle of freedom of contract, resulting in APHT being null and void. A form of internal legal protection given back to the principal agreement, i.e. a credit agreement made by the parties. External legal protection is legal protection provided by legislation, namely provided by Article 1131 and Article 1132 of the Civil Code, namely as holders of general guarantees known as concurrent creditors or conducting credit restructuring as an effort to save credit.

Penelitian ini memiliki 2 (dua) tujuan. Pertama, yakni untuk menganalisis konsekuensi hukum terhadap SKMHT yang terdegradasi menjadi akta dibawah tangan dan telah ditindaklanjuti pembuatan APHT serta didaftarkan di Kantor Pertanahan Kabupaten Bantul. Tujuan yang kedua adalah untuk menganalisis perlindungan hukum terhadap kreditur akibat SKMHT yang terdegradasi sebagai akta dibawah tangan. Penelitian ini adalah penelitian hukum normatif empiris. Hasil penelitian menunjukan bahwa APHT yang dibuat berdasarkan SKMHT tidak melanggar syarat subjektif dan syarat objektif sahnya perjanjian dan asas kebebasan berkontrak sehingga mengakibatkan APHT menjadi batal demi hukum. Kedua, perlindungan hukum terhadap kreditur meliputi perlindungan hukum internal dan eksternal. Secara internal, perlindungan hukum diberikan oleh perjanjian pokoknya, yaitu perjanjian kredit, dan secara eksternal, perlindungan hukum diberikan oleh peraturan perundang-undangan yaitu diberikan oleh Pasal 1131 dan Pasal 1132 KUHPerdata yakni sebagai pemegang jaminan umum yang dikenal sebagai kreditur konkuren atau melakukan restrukturisasi kredit sebagai upaya penyelamatan kredit. 


\section{A. PENDAhuluan}

Bank mempunyai peran penting terhadap perekonomian suatu negara. Kasmir mengartikan bank secara sederhana sebagai lembaga keuangan yang kegiatan utamanya adalah menghimpun dana dari masyarakat dan menyalurkan kembali dana tersebut kepada masyarakat serta memberikan jasa bank lainnya. ${ }^{1}$ Kegiatan penyaluran dana oleh bank kepada masyarakat yang membutuhkan, dalam praktik selalu diikuti dengan perjanjian tambahan (accesoir) berupa jaminan. Jaminan berperan penting dalam lalu lintas penyaluran dana kepada masyarakat dengan tujuan untuk melindungi kreditur baik keamanan maupun kepastian hukum dalam pelaksanaan pemenuhan prestasi oleh debitur. Praktiknya, jaminan tanah dimanfaatkan oleh kreditur untuk dijadikan sebagai pelindung, baik kepastian maupun keamanan dalam lalu lintas perkreditan dengan pengikatan hak tanggungan.

Pemberian hak tanggungan harus dilakukan dengan pembuatan Akta Pemberian Hak Tanggungan (selanjutnya disebut APHT) yang dibuat di hadapan PPAT dan wajib dihadiri oleh pemberi hak tanggungan, penerima hak tanggungan (kreditur) serta disaksikan 2 orang saksi. Hak tanggungan tidak lahir hanya dengan penandatanganan APHT melainkan perlu ditindaklanjuti dengan pendaftaran di kantor pertanahan setempat di mana tanah yang dijadikan objek jaminan itu terletak. Prinsipnya pada tahap pemberian hak tanggungan pemberi hak tanggungan wajib hadir dihadapan PPAT, namun dalam keadaan tertentu pemberi hak tanggungan tidak dapat hadir maka wajib menunjuk pihak lain sebagai kuasanya, dengan pembuatan Surat Kuasa Membebankan Hak Tanggungan (selanjutnya disebut SKMHT).

Secara formil, SKMHT wajib dibuat dalam bentuk akta autentik baik berupa akta notaris atau akta PPAT, dan harus memenuhi ketentuan sebagaimana diatur dalam Pasal 15 ayat (1) Undang-Undang Nomor 4 Tahun 1996 Tentang Hak Tanggungan Atas Tanah Beserta Benda-Benda Yang Berkaitan Dengan Tanah (selanjutnya disebut UUHT). SKMHT yang khusus dibuat oleh PPAT, berdasarkan Pasal 96 Peraturan Kepala Badan Pertanahan Nasional Nomor 8 Tahun 2012 tentang Perubahan Atas Peraturan Menteri Agraria/Kepala Badan Pertanahan Nasional Nomor 3 Tahun 1997 tentang Ketentuan Pelaksanaan Peraturan Pemerintah Nomor 24 Tahun 1997 tentang Pendaftaran Tanah (selanjutnya disebut Perkaban 8/2012) menyebutkan bahwa SKMHT harus dibuat sesuai dengan tata cara pengisian yang dilampirkan di dalam Perkaban 8/2012 tersebut. Khusus pembuatan SKMHT dengan akta notaris tidak diatur secara tegas di dalam Perkaban tersebut, namun akta notaris dapat dikualifikasi sebagai akta autentik apabila memenuhi bentuk akta yang diatur didalam Pasal 38 Undang-Undang Nomor 2 Tahun 2014 tentang Perubahan Atas UndangUndang Nomor 30 Tahun 2004 Tentang Jabatan Notaris (selanjutnya disebut UUJNP). ${ }^{2}$

1 Kasmir, Bank Dan Lembaga Keuangan Lainnya. Raja Grafindo Persada, Jakarta, 2015, hal. 25

2 J. Satrio, Hukum Jaminan, Hak Jaminan Kebendaan, Hak Tanggungan, Citra Aditya Bakti, Bandung, 2004, hal. 174. 
Akta notaris sebagaimana diatur dalam Pasal 1 angka 7 UUJNP adalah akta autentik yang dibuat oleh atau dihadapan notaris menurut bentuk dan tata cara yang ditetapkan dalam UUJNP. Salah satu syarat akta notaris dapat dikualifikasi sebagai akta autentik apabila pembuatan akta telah memenuhi bentuk akta yang ditentukan dalam Pasal 38 UUJNP. Akta notaris akan terdegradasi menjadi akta dibawah tangan apabila tidak memenuhi ketentuan Pasal 38 UUJNP. Kartini Muljadi dan Gunawan Widjaja berpendapat bahwa SKMHT yang tidak dibuat dengan bentuk akta notaris atau akta PPAT maka konsekuensinya adalah tidak berlaku sebagai SKMHT. ${ }^{3}$

Berdasarkan prapenelitian penulis, notaris dalam praktiknya di Kabupaten Bantul membuat SKMHT menggunakan bentuk format yang disediakan dalam Lampiran VIIIa Perkaban 8/2012. Penggunaan bentuk yang ditentukan dalam lampiran Perkaban 8/2012 pada SKMHT tersebut mengakibatkan bentuk akta yang diatur dalam Pasal 38 UUJNP menjadi tidak terpenuhi. Penulis juga menemukan fakta bahwa SKMHT yang dibuat di hadapan notaris tersebut tidak sesuai dengan Pasal 38 UUJNP tersebut dijadikan dasar pembuatan APHT dan didaftarkan di Kantor Pertanahan Kabupaten Bantul.

SKMHT yang terdegradasi menjadi akta di bawah tangan tersebut secara normatif tidak dapat dijadikan dasar pembuatan APHT karena tidak memenuhi syarat autentitas yang ditentukan dalam Pasal 15 ayat (1) UUHT. SKMHT yang tidak memenuhi syarat autentitas tersebut akan berimplikasi pada tidak terjadinya pemberian hak tanggungan dengan pembuatan APHT secara tidak langsung serta tidak melahirkan suatu hak tanggungan sebagai jaminan bagi kreditur. Akibatnya adalah tidak terjaminnya kedudukan kreditur dalam hubungan utang piutang, baik dalam pemenuhan prestasi maupun terjadinya wanprestasi yang dilakukan oleh debitur.

Penulis tidak menemukan penelitian terdahulu dengan pembahasan maupun obyek penelitian yang serupa, namun ada beberapa peneliti terdahulu yang membahas mengenai SKMHT yang dibuat di hadapan notaris, yaitu: Pertama oleh Erma Zulfa Kurniawan (2017) dengan tesis yang berjudul Perbandingan Otentitas Surat Kuasa Membebankan Hak Tanggungan Yang Dibuat Di Hadapan Notaris Dengan Pejabat Pembuat Akta Tanah. Kedua oleh Masykur Burhan (2011) dengan tesis yang berjudul Otentitas Surat Kuasa Membebankan Hak Tanggungan Yang Dibuat Notaris Berdasarkan Undang-Undang Nomor 30 Tahun 2004 Tentang Jabatan Notaris. Kedua peneliti tersebut pada prinsipnya membahas mengenai autentitas SKMHT yang dibuat di hadapan notaris dengan hasil penelitian bahwa SKMHT yang dibuat di hadapan notaris kehilangan autentitas sebagai akta autentik dan SKMHT tersebut terdegradasi sebagai akta di bawah tangan.

Penelitian sebelumnya berbeda dengan penelitian yang diangkat oleh penulis yang membahas mengenai perlindungan hukum terhadap kreditur akibat SKMHT yang terdegradasi sebagai akta di bawah tangan. Penelitian ini merupakan penelitian lanjutan dari penelitian terdahulu, yang

3 Kartini Muljadi dan Gunawan Widjaja, Seri Hukum Harta Kekayaan : Hak Tanggungan, Jakarta, Prenada Media, 2005, hal. 191. 
hasil penelitiannya hanya sampai pada SKMHT terdegradasi menjadi akta di bawah tangan, namun tidak membahas mengenai bagaimana konsekuensi hukum terhadap SKMHT yang terdegradasi menjadi akta di bawah tangan dan telah ditindaklanjuti pembuatan APHT, dan perlindungan hukum terhadap kreditur akibat SKMHT yang terdegradasi sebagai akta di bawah tangan.

\section{B. METODE PENELITIAN}

Penelitian ini merupakan penelitian yang bersifat deskriptif yang ditunjukkan untuk memberikan data dengan seteliti mungkin mengenai manusia, keadaan atau gejala-gejala lainnya. ${ }^{4}$ Penelitian ini merupakan jenis penelitian hukum normatif empiris. Penelitian hukum normatif dilakukan dengan meneliti bahan pustaka atau data sekunder mengenai akibat SKMHT notaris yang terdegradasi sebagai akta di bawah tangan dan dijadikan dasar pembuatan APHT. Penulis menggunakan jenis penelitian hukum normatif terhadap taraf sinkronisasi vertikal maupun horizontal dari bahan hukum primer. Penelitian hukum empiris metode sosial yang nomologis induktif dari kajian sociology of law. Metode ini mengkonsepkan hukum secara sosiologis sebagai suatu gejala empiris yang dapat diamati dalam kehidupan. ${ }^{5}$ Penelitian hukum empiris merupakan penelitian yang difokuskan pada fakta sosial dengan cara mengumpulkan data primer yang diperoleh di lapangan, yaitu mengenai akibat SKMHT notaris yang terdegradasi sebagai akta di bawah tangan dan dijadikan dasar pembuatan APHT. Penelitian ini dilakukan di Daerah Istimewa Yogyakarta, khususnya di Kabupaten Bantul, karena objek yang diteliti yaitu SKMHT yang terdegradasi menjadi akta di bawah tangan dijadikan sebagai dasar pembuatan APHT dan didaftarkan di Kantor Pertanahan Kabupaten Bantul.

\section{PEMBAHASAN}

1. Konsekuensi hukum terhadap SKMHT yang terdegradasi menjadi akta di bawah tangan dan telah ditindaklanjuti pembuatan APHT serta didaftarkan di Kantor Pertanahan Kabupaten Bantul

\section{a. SKMHT yang Terdegradasi sebagai Akta di Bawah Tangan Tidak Lahir}

Notaris dan PPAT merupakan pejabat yang berbeda, namun kadang kala dalam membuat suatu akta kedua pejabat tersebut saling bersinggungan satu sama lain. Pembuatan APHT oleh PPAT yang didasarkan pada SKMHT yang dibuat dengan akta notaris merupakan salah satu contohnya. Penjelasan Pasal 15 UUHT menjelaskan bahwa prinsipnya pembuatan APHT wajib dihadiri oleh pemberi hak tanggungan di hadapan PPAT, baik pemberi hak tanggungan yang berupa perorangan maupun badan hukum. Pemberi hak tanggungan dapat hadir di hadapan PPAT maka metode pembuatan APHT dapat dilakukan secara langsung tanpa menggunakan SKMHT. SKMHT dapat

4 Soerjono Soekanto, Pengantar Penelitian Hukum, UI-Press, Jakarta, 1986, hal.10.

5 Ibid., hal. 161. 
digunakan apabila dalam keadaan tertentu yang mengakibatkan pemberi hak tanggungan tidak dapat hadir di hadapan PPAT untuk menandatangani APHT. Pembuatan APHT secara tidak langsung melalui pemberian kuasa kepada pihak lain untuk membebankan hak tanggungan (SKMHT) baik berbentuk akta notaris ataupun akta PPAT.

Berdasarkan data yang diperoleh penulis dari Bapak Sigit Pramuliyanto bahwa pendaftaran hak tanggungan di Kantor Pertanahan Kabupaten Bantul dari bulan Januari hingga Juli tahun 2020 sebanyak 2074 (dua ribu tujuh puluh empat) hak tanggungan. Data yang diperoleh menunjukan bahwa selama bulan Januari sampai Juli 2020 terdapat pendaftaran hak tanggungan dengan metode pembuatan APHT secara tidak langsung, yaitu sebanyak 191 (seratus sembilan puluh satu), atau kurang lebih $10 \%$ dari seluruh jumlah pendaftaran hak tanggungan tersebut diatas dan di dominasi penggunaan SKMHT yang dibuat dalam bentuk akta notaris. Adapun penerima hak tanggungan pada praktiknya adalah berbadan hukum baik itu Perusahaan Terbatas maupun Koperasi. ${ }^{6}$

SKMHT adalah akta pemberian kuasa khusus untuk membuat APHT. SKMHT dibuat guna menjadi jembatan untuk mewujudkan pembuatan APHT di kemudian hari, dikarenakan pada saat itu APHT belum bisa dibuat sehingga terpaksa dibuat SKMHT terlebih dahulu. ${ }^{7}$ Pasal 15 ayat (1) UUHT menentukan SKMHT dapat dibuat dalam bentuk akta notaris atau akta PPAT. Definisi akta notaris diatur dalam Pasal 1 angka 7 UUJNP yaitu "akta autentik yang dibuat oleh atau di hadapan Notaris menurut bentuk dan tata cara yang ditetapkan dalam Undang-Undang Jabatan Notaris". Pemahaman mengenai akta notaris juga perlu dikaitkan dengan ketentuan Pasal 1868 jo. Pasal 1869 KUHPerdata. Kedua Pasal merupakan sumber untuk autentitas akta notaris juga merupakan dasar legalitas eksistensi akta notaris. ${ }^{8}$ Pasal 1868 KUHPerdata berbunyi "suatu akta autentik ialah suatu akta yang dibuat dalam bentuk yang ditentukan undang-undang oleh atau dihadapan pejabat umum yang berwenang untuk itu di tempat akta itu dibuat". Pengertian akta autentik tersebut dapat terbagi menjadi 3 (tiga) unsur agar suatu akta memenuhi syarat formal menjadi akta autentik yakni dibuat dalam bentuk yang ditentukan oleh undangundang, dibuat oleh atau dihadapan pejabat umum, dan ditempat dimana akta itu dibuat. Pasal 1 angka 7 UUJNP dan Pasal 1868 KUHPerdata menyatakan bahwa suatu akta notaris dapat dikatakan sebagai akta autentik apabila memenuhi bentuk yang ditentukan dalam undang-undang. Akta notaris yang dibuat setelah lahirnya UUJN harus mendapat pengukuhan karena bentuk akta ditentukan oleh undang-undang. Bentuk akta notaris sebagaimana diatur dalam Pasal 38 UUJNP.

6 Hasil wawancara dengan Bapak Sigit Pramuliyanto selaku Kepala Seksi Pendaftaran Tanah di Kantor Pertanahan Kabupaten Bantul, tanggal 08 September 2020, Pukul 10.00 WIB.

7 Mustofa, Tuntunan Pembuatan Akta-Akta PPAT, Karya Media, Yogyakarta, 2014, hal. 299. 8 Habib Adjie, Pemahaman Terhadap Bentuk SKMHT, Mandar Maju, Bandung, 2019, hal. 19. 
SKMHT yang dibuat di hadapan notaris merupakan akta para pihak. Habib Adjie yang menyatakan bahwa dalam pembuatan akta notaris termasuk SKMHT maka harus tetap tunduk pada ketentuan yang diatur pada UUJNP. Herlien Budiono dalam buku Habib Adjie juga senada dengan pendapat Habib Adjie bahwa notaris telah ada UUJN maka ketentuan membuat akta harus tunduk pada ketentuan Pasal 38 UUJNP. SKMHT yang dibuat dalam bentuk akta notaris harus sesuai dengan ketentuan tata cara pembuatan dan bentuk akta notaris sebagaimana diatur pada UUJN/UUJNP, asalkan isi SKMHT dibuat sesuai dengan syarat dan ketentuan yang telah diatur pada Pasal 15 ayat (1) UUHT.

SKMHT yang dibuat dalam bentuk akta PPAT berdasarkan Pasal 21 ayat (1) PP 37/1998 yang pada pokoknya mengatur bahwa akta PPAT dibuat sesuai bentuk akta yang ditentukan oleh Menteri. Pengaturan ini juga ditegaskan pada Pasal 38 ayat (2) Peraturan Pemerintah Nomor 24 Tahun 1997 tentang Pendaftaran Tanah (selanjutnya disebut PP 24/1997). Dewasa ini peraturan pelaksana PP 24/1997 yang mengatur mengenai bentuk akta PPAT terdapat di dalam Perkaban 8/2012. Bentuk akta sebagaimana diatur dalam Perkaban 8/2012 mengakibatkan setiap PPAT yang membuat akta harus mematuhi bentuk akta yang ditentukan dalam Perkaban 8/2012 guna memenuhi syarat berlakunya akta PPAT sebagai akta autentik. Herlien Budiono mengemukakan bahwa bentuk akta kuasa yang dibuat dengan akta PPAT harus memenuhi ketentuan yang disyaratkan pada Perkaban 8/2012. ${ }^{10}$

Notaris dan PPAT tunduk pada 2 (dua) aturan yang berbeda. Notaris dalam membuat akta harus tunduk pada bentuk akta yang ditentukan pada Pasal 38 UUJN, sedangkan PPAT harus tunduk pada Perkaban 8/2012. Pejabat dalam menjalankan jabatannya tentunya harus tunduk pada peraturan perundang-undangan sesuai dengan kapasitasnya. Hasil penelitian menunjukan praktik yang terjadi di lapangan bahwa notaris dalam membuat SKMHT yang akan digunakan sebagai dasar pembuatan APHT untuk objek tanah yang terletak di Kabupaten Bantul mengikuti ketentuan bentuk akta yang diatur dalam Lampiran VIIIa Perkaban 8/2012. Penulis melakukan perbandingan bentuk akta yang ditentukan dalam Pasal 38 UUJNP dengan bentuk akta SKMHT yang ditentukan dalam Lampiran VIIIa Perkaban 8/2012. Hasil penelitian menunjukan praktik yang terjadi di lapangan bahwa notaris dalam membuat SKMHT dalam bentuk akta notaris di Kabupaten Bantul mengikuti ketentuan bentuk akta yang diatur dalam Lampiran VIIIa Perkaban 8/2012. Penulis melakukan perbandingan bentuk akta yang ditentukan dalam Pasal 38 UUJNP dengan bentuk akta SKMHT yang ditentukan dalam Lampiran VIIIa Perkaban 8/2012. Hasil dari perbandingan tersebut penulis menemukan ada beberapa

9 Habib Adjie, Hukum Notaris Indonesia (Tafsir Tematik Terhadap Undang-Undang Nomor 30 Tahun 2004), PT Refika Aditama, Bandung, 2014, hal. 79.

10 Ibid. 
unsur yang ditentukan pada Pasal 38 UUJNP tidak terpenuhi dalam bentuk akta yang ditentukan Perkaban 8/2012. Berikut beberapa unsur bentuk akta notaris yang tidak terpenuhi di dalam SKMHT yang ditentukan dalam Perkaban 8/2012 :

1) Jam pembuatan akta SKMHT (dibagian awal akta);

2) Tempat penandatanganan akta (dibagian akhir akta);

3) Uraian tentang ada tidaknya perubahan yang terjadi dalam SKMHT (dibagian akhir akta).

Tidak terpenuhinya beberapa unsur sebagaimana diatur pada Pasal 38 UUJNP mengakibatkan SKMHT tersebut tidak dapat diklasifikasi sebagai akta autentik. Ketentuan Pasal 41 UUJNP menyatakan bahwa jika akta notaris tidak memenuhi bentuk akta yang ditentukan pada Pasal 38 UUJNP maka mengakibatkan akta notaris terdegradasi menjadi akta di bawah tangan.

Penjelasan umum angka 7 UUHT memerintahkan bahwa SKMHT harus berbentuk autentik. Penjelasan Pasal 15 ayat (1) UUHT hanya mengatur batal demi hukum jika syarat materil tidak terpenuhi, namun untuk syarat formil terkait bentuk akta tidak diatur akibat hukumnya. Ketentuan mengenai bentuk SKMHT tersebut terlihat hanya sebagai Lex Imperfecta atau kaidah hukum tanpa sanksi. SKMHT yang terdegradasi menjadi akta di bawah tangan pada sisi lain juga tidak memenuhi ketentuan Pasal 15 ayat (1) UUHT yang mengatur SKMHT harus berbentuk autentik. Akibat tidak terpenuhinya ketentuan SKMHT yang diatur pada UUHT maka secara normatif SKMHT yang terdegradasi menjadi di bawah tangan tidak dapat dijadikan dasar pembuatan APHT.

SKMHT ditinjau dari lahirnya perjanjian merupakan perjanjian formil. SKMHT lahir tidak cukup hanya dengan kata sepakat, namun juga harus memenuhi formalitas-formalitas yang ditentukan dalam peraturan perundang-undangan. Formalitas yang harus dipenuhi pada SKMHT sebagaimana diatur dalam Pasal 15 UUHT. Salah satunya formalitas yang harus dipenuhi pada SKMHT adalah wajib dibuat dengan akta notaris atau akta PPAT yang bersifat autentik. Praktiknya SKMHT yang dibuat di hadapan notaris menggunakan bentuk akta sebagaimana terlampir pada Lampiran VIIIa Perkaban 8/2012 sehingga akibatnya terdegradasi menjadi akta di bawah tangan. SKMHT tersebut yang dibuat berdasarkan Lampiran VIIIa Perkaban 8/2012 akan mengakibatkan formalitas SKMHT yang harus berbentuk autentik menjadi tidak dipenuhi. SKMHT berbentuk akta notaris yang dibuat tidak memenuhi ketentuan Pasal 38 UUJNP yang tidak memenuhi formalitas autentitas sebagaimana diatur pada Pasal 15 ayat (1) UUHT mengakibatkan SKMHT yang terdegradasi tersebut menjadi tidak lahir karena bukan SKMHT yang dimaksud dalam UUHT.

\section{b. APHT Batal Demi Hukum}

APHT menurut Munir Fuady adalah suatu janji yang menyatakan bahwa terhadap utang piutang tertentu dijamin 
pembayarannya dengan pemberian suatu hak tanggungan dari pemberi hak tanggungan kepada kreditur. $^{11}$ APHT merupakan perjanjian accesoir atas utang piutang yang sebagai perjanjian pokok sehingga keduanya tidak dapat dipisahkan. Dalam pembuatan APHT harus memperhatikan ketentuan Pasal 11 ayat (1) dan (2) UUHT. Selain itu juga harus memenuhi syarat sahnya perjanjian sebagaimana diatur dalam ketentuan Pasal 1320 KUHPerdata. Pembuatan suatu APHT dapat dibuat secara langsung ataupun secara tidak langsung. APHT yang dibuat secara tidak langsung yang dimaksud adalah melalui SKMHT.

SKMHT berisi mengenai kesepakatan antara pemberi dan penerima kuasa untuk membebankan hak tanggungan terhadap objek hak tanggungan. SKMHT yang tidak lahir berdasarkan hukum mengakibatkan segala perbuatan hukum yang diperjanjikan di dalamnya tidak pernah ada. Fakta di lapangan menunjukan SKMHT berbentuk akta notaris yang tidak memenuhi ketentuan Pasal 38 UUJNP tersebut sehingga mengakibatkan SKMHT yang tidak lahir tersebut tetap dapat dijadikan dasar pembuatan APHT. Penggunaan SKMHT yang tidak lahir tersebut tentu akan mempengaruhi keabsahan terhadap suatu APHT.

APHT merupakan perjanjian formil yaitu lahirnya suatu APHT tidak cukup dengan kata sepakat namun harus memenuhi formalitas tertentu sebagaimana ditentukan dalam UUHT. Perjanjian formil merupakan perkecualian dari asas konsensualisme yang menyatakan bahwa perjanjian lahir sejak adanya kata sepakat. APHT dapat dibuat secara langsung dan secara tidak langsung. APHT yang dibuat secara tidak langsung wajib menggunakan SKMHT. SKMHT yang tidak lahir karena bukan SKMHT sebagaimana yang dimaksud dalam Pasal 15 ayat (1) UUHT lazimnya tidak dapat digunakan untuk menjembatani pembuatan APHT. Segala perbuatan yang diperjanjikan di dalam SKMHT termasuk kesepakatan terkait pemberian kuasa kepada penerima kuasa (kreditur) untuk mewakilinya melakukan pemberian hak tanggungan tidak pernah ada. APHT yang dibuat berdasarkan SKMHT yang tidak lahir di lapangan telah lahir suatu APHT, namun tanpa kesepakatan antara para pihak sehingga akan mempengaruhi keabsahan terhadap APHT yang lahir tersebut. APHT yang dibuat tersebut tidak memenuhi ketentuan syarat kesepakatan dalam 1320 KUHPerdata.

Subjek hukum dalam melakukan perbuatan hukum pembebanan hak tanggungan harus mempunyai kecakapan, baik cakap bertindak maupun wenang bertindak. Wenang bertindak dapat berupa untuk wenang bertindak untuk kepentingan diri sendiri atau untuk kepentingan orang lain. Khusus wenang bertindak untuk kepentingan pihak lain dalam pembebanan hak tanggungan maka dasar wenang bertindaknya adalah berdasarkan pemberian kuasa SKMHT. Praktik di lapangan pemberi hak tanggungan dalam APHT

11 Munir Fuady, Hukum Jaminan Utang, PT. Gelora Aksara Pratama, Jakarta, 2013, hal. 82-83. 
diwakili oleh penerima kuasa (kreditur) berdasarkan SKMHT yang tidak lahir sehingga pemberi hak tanggungan dalam APHT tersebut merupakan pihak yang tidak mempunyai kewenangan. Penerima kuasa berdasarkan SKMHT yang tidak lahir dalam pembuatan APHT adalah pihak yang memenuhi syarat kecakapan.

Akibatnya tidak terpenuhinya syarat subjektif sahnya perjanjian diatas mengakibatkan APHT tersebut dapat dimintakan pembatalan melalui permohonan ke pengadilan. APHT tersebut tidak hanya melanggar syarat subjektif, namun juga melanggar syarat objektif sahnya perjanjian sebagaimana diatur dalam Pasal 1320 KUHPerdata.

Objek yang diperjanjikan wajib dipenuhi dalam membuat suatu perjanjian. Kejelasan suatu objek perjanjian untuk memberikan kepastian pelaksanaan hak dan kewajiban para pihak. Objek perjanjian yang tidak jelas mengakibatkan perjanjian tidak mungkin untuk dilaksanakan. Objek dalam pemberian hak tanggungan adalah tanah sebagaimana diatur pada Pasal 4 UUHT. SKMHT berisi pemberian kuasa kepada penerima kuasa untuk membebankan terhadap objek tertentu. SKMHT yang tidak lahir mengakibatkan tidak adanya objek yang diperjanjikan untuk dibebankan hak tanggungan. Akibatnya ketentuan objek tertentu yang diatur dalam syarat sahnya perjanjian menjadi tidak terpenuhi.

APHT yang dibuat berdasarkan SKMHT yang tidak pernah lahir selain tidak memenuhi syarat objek tertentu, juga tidak memenuhi syarat kausa yang halal. Kausa yang halal diatur pada Pasal 1320 KUHPerdata, dan diatur lebih lanjut pada Pasal 1335-1337 KUHPerdata. Pasal 1335 KUHPerdata menentukan bahwa suatu perjanjian yang dibuat tanpa sebab atau dibuat dengan sebab palsu atau terlarang tidak mempunyai kekuatan mengikat. Perjanjian yang tidak menyatakan suatu sebab namun tidak melanggar larangan tersebut maka perjanjian tetap sah. Pasal 1337 KUHPerdata menegaskan suatu sebab adalah terlarang jika sebab itu dilarang oleh undang-undang, kesusilaan atau ketertiban umum. Tri Wahyu Surya Lestari berpendapat sebab dikatakan terlarang jika bertentangan dengan undang-undang, misalnya Pasal 31 ayat (1) Undang-Undang Nomor 24 Tahun 2009 tentang Bendera, Bahasa, dan Lambang Negara serta Lagu Kebangsaan, yang pada pokoknya mengatur dalam nota kesepahaman atau perjanjian yang melibatkan lembaga negara, instansi pemerintah, lembaga swasta Indonesia ataupun perseorangan warga negara indonesia wajib menggunakan bahasa Indonesia. Tidak dipenuhi ketentuan Pasal 31 ayat (1) UU 24/2009, maka dikategorikan sebagai suatu bentuk pelanggaran terhadap undang-undang. Perjanjian yang melibatkan pihak asing bila tidak menggunakan bahasa Indonesia maka perjanjian batal demi hukum. ${ }^{12}$

12 Tri Wahyu Surya Lestari dan Lukman Santoso, Komparasi Syarat Keabsahan Sebab yang Halal dalam Perjanjian Konvensional dan Perjanjian Syariah, Yudisia: Jurnal Pemikiran Hukum dan Hukum Islam, Vol.08 No.2, 2017, hal. 288. 
Hemat penulis, Penjelasan umum angka 7 dan Penjelasan Pasal 15 UUHT menegaskan apabila pemberi hak tanggungan tidak dapat hadir pada saat pembuatan APHT, maka ia wajib menunjuk pihak lain sebagai kuasanya dengan membuat SKMHT yang berbentuk autentik. Kewajiban adanya SKMHT pada pembuatan APHT secara tidak langsung merupakan perintah yang bersifat memaksa ( $d$ wingenrecht). Ketiadaan SKMHT pada pembuatan APHT secara tidak langsung mewajibkan PPAT untuk menolak permohonan pembuatan APHT. Ketentuan tersebut mengakibatkan pembuatan APHT hanya terdapat 2 kemungkinan yaitu pembuatan APHT secara langsung atau pembuatan APHT secara tidak langsung dengan syarat wajib disertai dengan pembuatan SKMHT. Praktik pembuatan APHT secara tidak langsung dengan menggunakan SKMHT yang tidak lahir karena SKMHT yang terbentuk bukan yang dimaksud dalam Pasal 15 ayat (1) UUHT sama dengan pembuatan APHT secara tidak langsung tanpa menggunakan SKMHT karena SKMHT tersebut dianggap tidak pernah lahir dan tidak pernah ada. Praktik pembuatan APHT secara tidak langsung berdasarkan SKMHT yang tidak lahir melanggar ketentuan UUHT. Prinsipnya ketiadaan SKMHT mengakibatkan tidak dapat dibuatnya APHT secara tidak langsung, sehingga harus beralih pembuatan APHT secara langsung.

Pihak pemberian hak tanggungan dalam APHT juga harus memenuhi ketentuan Pasal 8 ayat (1) UUHT yang mengatur pemberi hak tanggungan baik orang perseorangan atau badan hukum harus merupakan pihak yang berwenang untuk melakukan pemberian hak tanggungan terhadap objek hak tanggungan yang bersangkutan. J. Satrio berpendapat bahwa Pasal 8 ayat (1) UUHT tidak lengkap sebab perbuatan hukum bisa meliputi perbuatan pengurusan (beheersdaden) dan perbuatan tindakan pemilikan (beschikkingsdaden). Perbuatan hukum berupa menjaminkan hak atas tanah merupakan tindakan kepemilikan, sehingga kesimpulannya adalah pemberi hak tanggungan harus mempunyai kewenangan perbuatan pemilikan atas benda jaminan yang bersangkutan. ${ }^{13}$ Praktik di lapangan pemberi hak tanggungan dalam APHT diwakili oleh penerima kuasa (kreditur) berdasarkan SKMHT yang tidak lahir sehingga pemberi hak tanggungan dalam APHT tersebut merupakan pihak yang tidak mempunyai kewenangan. Penerima kuasa berdasarkan SKMHT yang tidak lahir dalam pembuatan APHT secara tidak langsung merupakan perbuatan yang bertentangan dengan Pasal 8 ayat (1) UUHT.

Praktik pembuatan APHT secara tidak langsung berdasarkan SKMHT yang tidak lahir melanggar syarat subjektif dan syarat objektif sahnya perjanjian. APHT yang tidak memenuhi syarat objektif mengakibatkan APHT tersebut batal demi hukum atau batal dengan sendirinya tanpa harus melakukan pembatalan melalui pengadilan. APHT yang batal demi hukum, sejak awal APHT tidak pernah lahir dan

13 J. Satrio, Hukum Jaminan, Hak-Hak Jaminan Kebendaan, PT. Citra Aditya Bakti, Bandung, 2002, hal. 287. 
tidak pernah ada dan segala perbuatan yang ada harus dikembalikan ke keadaan semula.

Dari perspektif asas kebebasan berkontrak, pembuatan APHT antara pemberi hak tanggungan dengan penerima hak tanggungan tidak boleh sebebas-bebasnya, namun ada pembatasan yang diberikan oleh undang-undang, ketertiban umum dan kesusilaan. Pemberi hak tanggungan sebagaimana dimaksud pada Pasal 8 ayat (1) UUHT adalah pemberi hak tanggungan yang berwenang melakukan perbuatan terhadap objek hak tanggungan, sedangkan penerima hak tanggungan adalah pihak yang berpiutang. SKMHT yang tidak lahir adalah SKMHT yang tidak pernah ada sehingga tidak menimbulkan hubungan hukum antara pihak pemberi kuasa dan penerima kuasa. Pembuatan APHT secara tidak langsung berdasarkan SKMHT yang tidak lahir bertentangan dengan Pasal 8 ayat (1) UUHT. Hal ini disebabkan pihak pemberi hak tanggungan yang diwakili oleh pihak lain (kreditur) tidak mempunyai kewenangan terhadap objek hak tanggungan. Pelanggaran-pelanggaran sebagaimana dikemukakan diatas mengakibatkan perjanjian APHT tersebut batal demi hukum.

Hemat penulis, PPAT punya kewajiban untuk menolak pembuatan akta PPAT. Penolakan permohonan pembuatan akta PPAT oleh PPAT dapat dilakukan karena hal-hal yang disebabkan sebagaimana diatur pada Pasal 39 Peraturan Pemerintah Nomor 24 Tahun 1997 tentang Pendaftaran Tanah (selanjutnya disebut PP 24/1997). Salah satu alasan PPAT wajib menolak pembuatan APHT apabila salah satu pihak (pemberi hak tanggungan) yang akan melakukan perbuatan hukum pembebanan hak tanggungan merupakan pihak yang tidak berhak atau tidak memenuhi syarat untuk bertindak demikian (Pasal 44 ayat (2) jo. Pasal 39 ayat (1) huruf c PP 24/1997). Praktik pembuatan APHT berdasarkan SKMHT yang tidak lahir secara hukum wajib ditolak oleh PPAT karena SKMHT yang tidak lahir mengakibatkan segala hal yang diperjanjikan dalam SKMHT tidak pernah ada, termasuk tidak ada pemberian kuasa oleh pemberi kuasa kepada penerima kuasa. Pemberi hak tanggungan yang diwakili oleh penerima kuasa berdasarkan SKMHT yang tidak lahir adalah pihak tidak memenuhi syarat untuk bertindak dalam pembuatan APHT. PPAT dalam melaksanakan tugasnya mengabaikan ketentuan Pasal 39 PP 24/1997 akan dikenakan sanksi administrasi sesuai Pasal 62 PP 24/1997 berupa teguran tertulis sampai pemberhentian dari jabatan sebagai PPAT oleh Menteri atau pejabat yang ditunjuk. Tindakan PPAT dalam membuat APHT berdasarkan SKMHT yang tidak lahir juga merupakan pelanggaran berat. Pasal 28 ayat (4) Peraturan Kepala Badan Pertanahan Nasional Nomor 1 Tahun 2006 Tentang Ketentuan Pelaksanaan Peraturan Pemerintah Nomor 37 Tahun 1998 Tentang Peraturan Jabatan Pejabat Pembuat Akta Tanah (selanjutnya disebut Perkaban 1/2006) jo. Lampiran II Peraturan Menteri Agraria dan Tata Ruang/Kepala Badan Pertanahan 
Nasional Republik Indonesia Nomor 2 Tahun 2018 tentang Pembinaan dan Pengawasan Pejabat Pembuat Akta Tanah. Pelanggaran berat yang dilakukan oleh PPAT dalam hal ini adalah pembuatan APHT di hadapan para pihak yang tidak berwenang melakukan perbuatan hukum. Sanksi terhadap PPAT yang melakukan pelanggaran berat tersebut sebagaimana diatur dalam Lampiran Permen ATR/BPN 2/2018 berupa pemberhentian dengan tidak hormat oleh Menteri ATR/BPN (Pasal 14 ayat (3) Permen ATR/BPN 2/2018).

Pemberlakuan bentuk akta pada SKMHT yang dibuat di hadapan notaris berdasarkan Perkaban 8/2012 adalah kebijakan yang ditentukan oleh Kantor Pertanahan Kabupaten Bantul mengenai pelaksanaan tugas jabatan PPAT, yang merupakan bagian dari pembinaan. Kebijakan tersebut yang mengakibatkan pada praktiknya PPAT tetap menerima SKMHT yang tidak pernah lahir tersebut. Hemat penulis, Kantor Pertanahan Kabupaten Bantul selaku pembina dan pengawas terhadap PPAT tidak mempermasalahkan kebijakan yang diterapkan tersebut sebab dalam perspektifnya sudah menganggap benar sehingga tidak bertindak terhadap PPAT yang membuat APHT berdasarkan SKMHT yang tidak pernah lahir. PPAT sebagai pihak yang diawasi oleh Kantor Pertanahan Kabupaten Bantul tentu akan mengikuti kebijakan yang diterapkan oleh Kantor Pertanahan Kabupaten Bantul karena adanya hubungan vertikal. Hasil wawancara dengan Bapak Sugi Sigit Mahanani Enarwanto, S.H., bahwa apabila notaris membuat SKMHT dengan bentuk yang ditentukan oleh UUJNP maka berkas akan ditolak oleh Kantor Pertanahan Kabupaten Bantul. Notaris dan PPAT tetap mengikuti kebijakan yang ditentukan oleh Kantor Pertanahan Kabupaten Bantul agar berkas tidak ditolak oleh Kantor Pertanahan Kabupaten Bantul dan guna menjamin kedudukan kreditur menjadi pemegang hak tanggungan.

Alasan Kantor Pertanahan Kabupaten Bantul menggunakan Perkaban 8/2012 dalam pembuatan SKMHT dengan bentuk akta notaris sebagai berikut:

1) Kantor Pertanahan Kabupaten Bantul tidak bisa masuk porsinya ke UUJN dan tetap tunduk pada Perkaban 8/2012 karena yang mendaftarkan hak tanggungan dan masuk ke Kantor Pertanahan Kabupaten Bantul itu adalah pejabat yang kedudukannya sebagai PPAT, bukan sebagai notaris.

2) Perkaban $8 / 2012$ merupakan petunjuk teknis bagi Kantor Pertanahan Kabupaten Bantul sekaligus Kantor Pertanahan Kabupaten Bantul sebagai pembina PPAT sehingga akta yang diterima oleh Kantor Pertanahan Kabupaten Bantul harus tunduk pada Perkaban 8/2012.

Hemat penulis, kebijakan yang diterapkan oleh Kantor Pertanahan Kabupaten Bantul terkait dengan SKMHT yang dibuat dalam bentuk akta notaris berdasarkan bentuk SKMHT yang ditentukan Perkaban 8/2012 tidak tepat. Kantor Pertanahan hanya mengambil langkah praktis tanpa mengindahkan teori-teori dan asasasas hukum yang baik dan benar. Kantor Pertanahan Kabupaten 
Bantul harus memperhatikan disinkronisasi aturan yang ada sebagai satu kesatuan sistem hukum. SKMHT yang dibuat di hadapan notaris harusnya tunduk pada UUJN dan bukan Perkaban 8/2012. SKMHT yang dibuat notaris harus dibuat berdasarkan bentuk akta yang ditentukan Pasal 38 UUJNP. Pasal 96 ayat (5) Perkaban 8/2012 mengatur Kepala Kantor Pertanahan berhak menolak pendaftaran akta PPAT yang tidak sesuai dengan bentuk akta yang ditentukan pada Lampiran Perkaban 8/2012. Kententuan tersebut hanya berlaku terhadap akta PPAT, bukan terhadap akta notaris sehingga Kepala Kantor Pertanahan Bantul seharusnya tidak menolak SKMHT yang dibuat dalam bentuk akta notaris berdasarkan UUJNP. Ketentuan Perkaban 8/2012 juga tidak dapat diterapkan terhadap akta notaris karena kedua jabatan bukan jabatan yang sama meskipun dijabat oleh orang yang sama. Pembuatan SKMHT dalam bentuk akta notaris dengan berpedoman pada Perkaban 8/2012 justru membuat SKMHT tidak memenuhi ketentuan Pasal 38 UUJNP sehingga tidak dapat diklasifikasi sebagai akta autentik sebagaimana ditentukan Pasal 15 ayat (1) UUHT. Keadaan sebagaimana dijelaskan diatas selain terjadinya disinkronisasi aturan, pada sisi lain juga terjadi penerapan yang tidak tepat oleh Kantor Pertanahan Kabupaten Bantul.

\section{Perlindungan Hukum Terhadap Kreditur Akibat SKMHT Yang Terdegradasi Sebagai Akta Di Bawah Tangan}

Prinsipnya setiap orang bisa melakukan upaya apa saja yang tidak dilarang oleh peraturan perundang-undangan dan berhak meminta perlindungan hukum apabila ada kepentingan untuk itu. Perlindungan hukum adalah perlindungan yang diakomodir oleh hukum sebagai upaya pemulihan atau penyeimbangan terhadap pelanggaran hak yang terjadi. Prof. Moch. Isnaeni membagikan sarana bentuk perlindungan hukum menjadi 2 (dua), yaitu: ${ }^{14}$

\section{a. Perlindungan Hukum Internal}

Perlindungan hukum internal pada dasarnya perlindungan hukum yang dikemas oleh para pihak sendiri dalam suatu perjanjian. Para pihak mengemas dalam klausula-klausula perjanjian yang diinginkan agar kepentingannya terakomodir. Kegiatan pemberian kredit oleh kreditur kepada debitur dikemaskan dalam perjanjian kredit. Perjanjian kredit tentu akan mengatur mengenai hak dan kewajiban para pihak yang harus dilaksanakan.

APHT merupakan perjanjian accesoir dari perjanjian pokok, yakni perjanjian kredit. Perjanjian kredit adalah perjanjian tidak bernama, yaitu perjanjian yang diatur diluar KUHPerdata. Bentuk perjanjian kredit dapat dibuat dalam bentuk akta autentik maupun akta di bawah tangan. Bentuk perjanjian yang demikian akan menimbulkan konsekuensi pada kekuatan pembuktian apabila

14 Moch. Isnaeni, Pengantar Hukum Jaminan Kebendaan, PT. Revka Petra Media, Surabaya 2016, hal. 159-163. 
dipergunakan oleh para pihak sebagai suatu alat bukti dalam persidangan.

Pasal 1868 KUHPerdata menyatakan bahwa aka autentik adalah akta yang dibuat dalam bentuk yang ditentukan oleh undang-undang, oleh atau di hadapan pejabat umum yang berwenang di tempat akta itu. Akta autentik mempunyai kekuatan pembuktian yang sempurna sebab akta dibuat oleh atau di hadapan pejabat yang berwenang. Akta tersebut dengan sendirinya dapat membuktikan ia sebagai akta autentik, yang kebenaran dari hal-hal yang dituangkan dalam akta itu harus diakui oleh hakim sebab akta autentik dianggap benar selama kebenaran itu tidak dapat dibuktikan sebaliknya. Akta autentik yang dipergunakan sebagai alat bukti di pengadilan cukup bagi hakim tanpa harus meminta alat bukti lainnya. Akta di bawah tangan merupakan akta yang dibuat oleh para pihak tanpa melibatkan pejabat umum yang berwenang untuk itu. Akta di bawah tangan dapat menjadi alat bukti yang sempurna apabila para pihak yang menandatangani akta tersebut mengakui tandatangan yang ada di dalam akta, yang berarti mengakui kebenaran apa yang tertulis dalam akta di bawah tangan. Keadaan apabila tandatangan tersebut disangkal oleh para pihak maka pihak yang mengajukan akta di bawah tangan sebagai alat bukti tersebut diwajibkan untuk membuktikan kebenaran tandatangan atau isi akta.

Hasil wawancara dengan salah satu anggota pengurus daerah Ikatan Notaris Indonesia Kabupaten Bantul, fakta di lapangan dalam pembuatan perjanjian kredit antara kreditur dan debitur tergantung kebijakan internal kreditur, khususnya bank. Perjanjian kredit pada praktiknya ada yang dibuat dengan bentuk akta autentik maupun akta di bawah tangan. Perjanjian kredit yang dibuat dalam bentuk akta di bawah tangan umumnya disertai dengan waarmerking oleh notaris atau di legalisasi oleh notaris. ${ }^{15}$ Perjanjian kredit dalam praktik demikian akan mempunyai kekuatan pembuktian yang berbeda pula. Bapak Mulyoto menyebutkan urutan kekuatan pembuktian suatu akta sebagai berikut: ${ }^{16}$

1) Akta notariil;

2) Akta dibawah tangan yang di legalisasi;

3) Akta dibawah tangan yang di waarmerking;

4) Akta dibawah tangan yang hanya sebatas dikuatkan oleh 2 (dua) orang saksi.

Perjanjian kredit saja tidak cukup untuk melindungi kreditur, sebab kreditur dalam kedudukannya hanya sebagai kreditur konkuren. Praktiknya dalam pembuatan perjanjian kredit juga disertai dengan klausula pemberian jaminan sebagai perjanjian tambahan. Pasal 10 ayat (1) UUHT menentukan bahwa perjanjian tambahan berupa hak

15 Hasil wawancara dengan salah satu Notaris/PPAT sekaligus anggota Pengurus Daerah INI Kabupaten Bantul, tanggal 03 Oktober 2020, Pukul 11.00 WIB.

16 Mulyoto, Perjanjian (Teknik, Cara Membuat, Dan Hukum Perjanjian Yang Harus Dikuasai), Cakrawala Media, Yogyakarta, 2012, hlm. 11-12. 
tanggungan merupakan perjanjian yang tidak terpisahkan dari perjanjian pokok, sehingga tanpa adanya klausula perjanjian tambahan dalam perjanjian kredit tersebut tidak mungkin melahirkan suatu perjanjian tambahan hak tanggungan.

Bentuk perlindungan hukum internal sebagaimana yang diberikan oleh perjanjian kredit dimulai dari pembuatan perjanjian accesoir yaitu pemberian hak tanggungan dengan pembuatan APHT di hadapan PPAT. Pembuatan APHT tidak cukup untuk melindungi kreditur, sehingga untuk melindungi kreditur maka APHT tersebut harus didaftarkan di kantor pertanahan setempat. Lahirnya hak tanggungan akan melindungi kepentingan kreditur dan kreditur juga mempunyai kedudukan sebagai kreditur preferen yaitu kreditur yang didahulukan dari pada kreditur lainnya. Kedudukan tersebut akan memberikan perlindungan bagi kreditur apabila debitur wanprestasi.

Penggunaan SKMHT yang tidak lahir berdasarkan hukum karena bukan yang dimaksud dalam Pasal 15 ayat (1) UUHT sebagai dasar pembuatan APHT dalam praktiknya berimplikasi pada APHT batal demi hukum. Kegiatan pemberian kredit yang tidak melahirkan perjanjian accesoir berupa hak tanggungan disebabkan APHT batal demi hukum sehingga akan menimbulkan permasalahan apabila debitur wanprestasi. Kreditur kurang memperoleh perlindungan dalam hubungan hukum utang piutang antara kreditur dengan debitur karena tidak mendapatkan jaminan khusus kebendaan berupa hak tanggungan. Konsekuensinya apabila debitur wanprestasi maka kreditur tidak mempunyai kewenangan untuk mengeksekusi terhadap tanah yang dijadikan objek hak tanggungan dalam perjanjian kredit dan tidak mempunyai hak preferensi dalam pemenuhan piutang oleh debitur.

Batalnya APHT tersebut mengakibatkan perjanjian accesoir menjadi tidak berarti bagi kreditur sebab meskipun diperjanjikan dalam perjanjian pokok namun tidak dapat digunakan sebagai perlindungan hukum bagi kreditur sendiri. Konsekuensinya adalah perlindungan hukum terhadap kreditur tidak maksimal karena hanya sebagai kreditur konkuren. Bentuk perlindungan hukum internal yang diberikan kembali kepada perjanjian pokok, yaitu perjanjian kredit yang dibuat oleh para pihak. perjanjian kredit dapat digunakan sebagai dasar untuk melakukan upaya hukum, baik litigasi maupun non litigasi.

\section{b. Perlindungan Hukum Eksternal}

Perlindungan hukum eksternal dibuat oleh penguasa melalui regulasi bagi kepentingan pihak yang lemah, sesuai dengan hakikat aturan perundang-undangan tidak boleh berat sebelah dan bersifat memihak, secara proporsional wajib diberikan perlindungan hukum yang seimbang sedini mungkin kepada pihak lainnya. Proses pembuatan perjanjian dimungkinkan ada pihak yang relatif lebih kuat posisinya dari pihak Fmitranya, namun dalam pelaksanaan perjanjian 
pihak yang semula kuat itu justru terjerumus menjadi pihak yang lemah, misalnya saat debitur wanprestasi, maka kreditur layak mendapatkan perlindungan hukum juga.

Kreditur yang tidak memegang jaminan khusus hak tanggungan tetap mendapatkan perlindungan dari undang-undang. Perlindungan hukum yang diberikan undang-undang kepada kreditur adalah jaminan umum sebagaimana diatur di Pasal 1131 KUHPerdata dan Pasal 1132 KUHPerdata. Pasal 1131 KUHPerdata menyatakan harta kekayaan debitur baik benda bergerak maupun tidak bergerak, baik yang ada sekarang maupun yang akan ada di kemudian hari menjadi jaminan utang untuk segala perikatan yang dibuat oleh debitur. Kehadiran Pasal 1131 KUHPerdata ini demi hukum menentukan harta kekayaan atau kebendaan milik debitur akan menjadi jaminan utang bagi semua kreditur yang memberi pinjaman terhadap debitur. Hak setiap kreditur atas hasil penjualan seluruh harta kekayaan debitur sebagaimana ditentukan pada Pasal 1132 KUHPerdata, yang pada pokoknya menentukan bahwa pembagian hasil penjualan harta kekayaan debitur dilakukan berdasarkan proporsionalitas. Jaminan umum tidak ada kreditur yang didahulukan diantara para kreditur sehingga semua kreditur bersifat konkuren, yaitu mempunyai kedudukan yang sama. Berbeda kondisinya jika kreditur hanya terdiri dari 1 (satu) orang saja, maka kreditur tersebut dapat memperoleh haknya dari seluruh hasil penjualan harta kekayaan milik debitur secara penuh apabila mencukupi. Cara pemenuhan yang dapat ditempuh dan diupayakan oleh kreditur. ${ }^{17}$

Hemat penulis, adanya jaminan umum ini memberikan perlindungan kepada kreditur, namun perlindungannya tidak maksimal karena jaminan umum melindungi kreditur hanya sebatas memberikan kedudukan kepada kreditur yang bersifat konkuren terhadap harta kekayaan debitur. Kreditur konkuren mempunyai kedudukan yang sama dan tidak ada yang didahulukan antara satu dengan lainnya. Kreditur konkuren dalam memperoleh pemenuhan haknya berupa piutang, akan ada kemungkinan hasil penjualan harta kekayaan debitur lebih kecil daripada utang-utang yang ada sehingga pemenuhan piutang dimungkinkan tidak penuh (tidak lunas). Hal ini dikarenakan hasil penjualan jaminan umum itu dibagi secara proporsional kepada kreditur-kreditur konkuren.

Kreditur mempunyai beberapa upaya untuk menyelesaikan masalah kredit macet yaitu, yang pertama adalah dilakukannya restrukturisasi atau yang kedua adalah eksekusi. Bank mempunyai kebijakan tersendiri terkait dengan penyelesaian masalah wanprestasi yang terjadi yaitu restrukturisasi kredit sebagai upaya penyelamatan kredit. Peraturan Bank Indonesia memberikan fasilitas restrukturisasi kredit sebagaimana diatur dalam ketentuan Peraturan Bank Indonesia Nomor 14/15/PBI/2012 tentang Penilaian Kualitas Aset Bank Umum.

17 Jamillah, Pelaksanaan Pasal 1131 KUHPerdata atas Jaminan Benda Milik Debitur, Mercatoria, Vol.10 No.2, 2017, hal.142. 
Pasal 1 angka 26 Peraturan Bank Indonesia Nomor 14/15/PBI/2012 tentang Penilaian Kualitas Aset Bank Umum, restrukturisasi kredit adalah upaya perbaikan yang dilakukan bank dalam kegiatan perkreditan terhadap debitur yang mengalami kesulitan untuk memenuhi kewajibannya, yang dilakukan antara lain:

1) Penurunan suku bunga kredit

2) Perpanjangan jangka waktu kredit

3) Pengurangan tunggakan bunga

4) Pengurangan tunggakan pokok kredit

5) Penambahan fasilitas kredit

6) Konversi kredit menjadi penyertaan modal sementara.

Restrukturisasi kredit tidak mudah dilakukan oleh bank sebab bank harus hati-hati dalam menerapkan kebijakan restrukturisasi karena harus menganalisis aspek-aspek sebagai berikut:

1) Debitur mengalami kesulitan pembayaran pokok dan/atau bunga kredit.

2) Debitur masih memiliki prospek usaha yang baik dan dinilai mampu memenuhi kewajiban setelah kredit direstrukturisasi.

Penyelesaian restrukturisasi tersebut tidak sepenuhnya selalu dapat menyelamatkan kredit tersebut. Restrukturisasi kredit dapat juga gagal apabila debitur tetap tidak membayar utangnya, disamping tidak memenuhi syarat untuk diberikan kebijakan restrukturisasi.

Penyelesaian sengketa yang bersifat hubungan privat harus diupayakan melalui cara non litigasi terlebih dahulu. Kelebihan penyelesaian sengketa non litigasi adalah untuk memperoleh win-win solution bagi para pihak, jangka waktu penyelesaiannya lebih cepat dibandingkan melalui litigasi dan lebih hemat biaya. Kelemahan dari non litigasi adalah ada pihak yang lebih kuat (bargaining position) dan ada pihak lebih lemah sehingga menimbulkan ketidakseimbangan kedudukan diantara para pihak serta kesepakatan yang telah dicapai tidak bersifat memaksa karena tergantung pada itikad baik dari pihak yang berkewajiban. Apabila upaya non litigasi telah dilaksanakan dan debitur tidak ada itikad baik dan tidak mau melaksanakan prestasinya maka ultimum remidium yang dapat ditempuh adalah dengan menggugat debitur memenuhi pelaksanaan kewajibannya melalui pengadilan.

Penyelesaian sengketa non litigasi dapat berupa negosiasi, mediasi, konsiliasi dan arbitrase. Hemat penulis, negosiasi merupakan upaya penyelesaian masalah wanprestasi yang lebih cocok digunakan oleh kreditur bank dibandingkan upaya non litigasi yang lain. Penyelesaian melalui negosiasi dilakukan oleh para pihak tanpa campur tangan dari pihak ketiga sehingga tidak perlu mengeluarkan biaya apapun untuk membayar jasa pihak ketiga seperti penyelesaian sengketa non litigasi lainnya, misalnya mediasi harus membutuhkan mediator sebagai pihak ketiga dalam menyelesaikan sengketa. Upaya penyelesaian sengketa non litigasi selain negosiasi merupakan 
alternatif yang dipilih sebab kreditur dalam praktiknya di dominasi oleh badan hukum berupa bank yang berorientasi pada profit oriented.

Tuntutan hak merupakan tindakan yang bertujuan untuk memperoleh perlindungan hak yang diberikan oleh pengadilan untuk mencegah adanya penghakiman sendiri (eigenrichting). Orang yang mengajukan tuntutan hak memerlukan atau berkepentingan akan perlindungan hukum sehingga ia mengajukan tuntutan hak ke pengadilan. $^{18}$ Tuntutan hak harus dilakukan oleh pihak yang mempunyai kepentingan hukum yang cukup. Ketentuan tersebut merupakan syarat utama untuk dapat diterimanya tuntutan hak itu oleh pengadilan guna diperiksa (point d'interest, point d'action). Eksekusi terhadap jaminan umum harus ada titel eksekutorial sebagai dasar untuk mengeksekusi. Dasar gugatan yang dapat digunakan adalah wanprestasi karena hubungan hukum ditimbulkan berdasarkan perjanjian. Wanprestasi adalah tidak terpenuhinya prestasi karena kesalahan debitur, yang kesalahannya menimbulkan kerugian. Pasal 118 ayat (1) Herzien Inlandsch Reglement (HIR) menentukan bahwa pengadilan yang berwenang mengadili perkara adalah pengadilan negeri tempat tinggal tergugat. Berdasarkan asas Actor Sequitor Forum Rei sebagaimana ditentukan tersebut maka gugatan wanprestasi harus diajukan ke Pengadilan dimana tergugat berdomisili.

Ada kemungkinan bahwa pihak lawan atau tergugat selama sidang berjalan, ia mengalihkan harta kekayaannya kepada orang lain sehingga apabila kemudian gugatan penggugat dikabulkan oleh pengadilan, putusan tersebut tidak dapat dilaksanakan karena tergugat tidak mempunyai harta kekayaan lagi. Penggugat mempunyai hak untuk mengajukan sita jaminan terhadap harta kekayaan debitur sebagai upaya menjamin haknya dengan penyitaan tersebut. Sita jaminan sebagaimana diatur dalam Pasal 197 ayat (9), dan Pasal 199 HIR, Pasal 212 dan Pasal 214 Rbg. Penyitaan ini dapat dilakukan berdasarkan perintah ketua pengadilan negeri atas permintaan kreditur atau penggugat (Pasal 227 ayat (1) HIR, Pasal 261 ayat $1 \mathrm{Rbg}) .{ }^{19}$ Benda-benda yang disita untuk kepentingan kreditur (penggugat) dibekukan yaitu disimpan untuk jaminan dan tidak boleh dialihkan atau dijual kepada pihak lain. Pengajukan sita jaminan ini harus ada dugaan yang beralasan bahwa debitur selama belum dijatuhkan putusan oleh hakim atau selama putusan belum dijalankan, debitur yang bersangkutan mencari akal untuk menggelapkan atau melarikan barangnya.

Upaya penyelesaian masalah kredit melalui litigasi bukan merupakan upaya yang diutamakan oleh kreditur bank. Upaya litigasi merupakan upaya terakhir apabila semua upaya non litigasi telah dilakukan dan debitur tetap tidak melakukan pelunasan utangnya

18 Sudikno Mertokusumo, Hukum Acara Perdata Indonesia, Cahaya Atma Pustaka, Yogyakarta, 2017 hal. 54.

19 Ibid., hal. 95. 
kepada kreditur. Penyelesaian sengketa melalui upaya litigasi membutuhkan waktu yang panjang dan biaya yang banyak sehingga tidak efektif bagi kreditur mengingat bank merupakan badan hukum yang profit oriented. Praktik yang terjadi di lapangan apabila terjadi masalah gugatan bukan terkait dengan masalah APHT yang melahirkan hak tanggungan.

\section{KESIMPULAN}

Berdasarkan pemaparan hasil penelitian serta pembahasan, maka penulis menarik kesimpulan bahwa: Pertama, SKMHT yang terdegradasi sebagai akta di bawah tangan tidak lahir sebagai SKMHT yang dimaksud dalam Pasal 15 ayat (1) UUHT. SKMHT yang tidak lahir tidak dapat dijadikan sebagai dasar pembuatan APHT. APHT yang dibuat berdasarkan SKMHT tidak lahir melanggar syarat subjektif dan syarat objektif sahnya perjanjian dan asas kebebasan berkontrak sehingga mengakibatkan APHT menjadi batal demi hukum. PPAT penerima pembuatan APHT berdasarkan SKMHT yang tidak lahir termasuk perbuatan pelanggaran berat sehingga dapat dikenakan sanksi administrasi berupa pemberhentian secara tidak hormat oleh menteri ATR/BPN. Kedua, Perlindungan hukum internal adalah perjanjian pokok, yaitu perjanjian kredit yang dibuat oleh para pihak. Perjanjian kredit dapat digunakan sebagai dasar untuk melakukan upaya hukum, baik litigasi maupun non litigasi. Perlindungan hukum eksternal adalah perlindungan hukum yang diberikan oleh peraturan perundangundangan yaitu diberikan oleh Pasal 1131 dan Pasal 1132 KUHPerdata yakni sebagai pemegang jaminan umum yang dikenal sebagai kreditur konkuren atau melakukan restrukturisasi kredit sebagai upaya penyelamatan kredit. Upaya penyelesaian masalah kredit melalui non litigasi dapat berupa negosiasi. Upaya litigasi yang dapat dilakukan adalah dengan mengajukan gugatan wanprestasi yang dilakukan oleh debitur terhadap perjanjian pokok. Upaya litigasi bukan merupakan upaya utama yang dilakukan oleh bank sebagai badan hukum yang profit oriented karena membutuhkan biaya yang besar.

\section{DAFTAR PUSTAKA}

\section{Buku}

Adjie, Habib, 2014, Hukum Notaris Indonesia (Tafsir Tematik Terhadap Undang-Undang Nomor 30 Tahun 2004), PT Refika Aditama, Bandung;

2019, Pemahaman Terhadap Bentuk SKMHT, Mandar Maju, Bandung;

Fuady, Munir, 2013, Hukum Jaminan Utang, PT Gelora Aksara Pratama, Jakarta;

Isnaeni, Moch, 2016, Pengantar Hukum Jaminan Kebendaan, PT. Revka Petra Media, Surabaya; 
Kasmir, 2015, Bank Dan Lembaga Keuangan Lainnya, Raja Grafindo Persada, Jakarta;

Mertokusumo, Sudikno., 2017, Hukum Acara Perdata Indonesia, Cahaya Atma Pustaka, Yogyakarta;

Muljadi, Kartini dan Gunawan Widjaja., 2005, Seri Hukum Harta Kekayaan: Hak Tanggungan, Prenada Media, Jakarta;

Mulyoto, 2012, Perjanjian (Teknik, Cara Membuat, Dan Hukum Perjanjian Yang Harus Dikuasai), Cakrawala Media, Yogyakarta;

Mustofa., 2014, Tuntunan Pembuatan Akta-Akta PPAT, Karya Media, Yogyakarta;

Satrio, J., 2002, Hukum Jaminan, Hak-Hak Jaminan Kebendaan, PT. Citra Aditya Bakti, Bandung;

., 2004, Hukum Jaminan, Hak Jaminan Kebendaan, Hak Tanggungan, Citra Aditya Bakti, Bandung;

Soekanto, Soerjono., 1986, Pengantar Penelitian Hukum, UI-Press, Jakarta;

\section{Jurnal}

Jamillah, Pelaksanaan Pasal 1131 KUHPerdata atas Jaminan Benda Milik Debitur, Mercatoria, Vol.10 No.2, 2017;

Lestari, Tri Wahyu Surya dan Lukman Santoso., Komparasi Syarat Keabsahan Sebab yang Halal dalam Perjanjian Konvensional dan Perjanjian Syariah, Yudisia: Jurnal Pemikiran Hukum dan Hukum Islam, Vol.8 No.2, 2017;

\section{Peraturan Perundang-Undangan}

Undang-Undang Nomor 4 Tahun 1996 tentang Hak Tanggungan Atas Tanah Beserta Benda-Benda Yang Berkaitan Dengan Tanah, Lembaran Negara Republik Indonesia Tahun 1996 Nomor 42, Tambahan Lembaran Negara Republik Indonesia Nomor 3632;

Undang-Undang Nomor 2 Tahun 2014 tentang Perubahan Atas UndangUndang Nomor 30 Tahun 2004 tentang Jabatan Notaris, Lembaran Negara Republik Indonesia Tahun 2014 Nomor 3, Tambahan Lembaran Negara Republik Indonesia Nomor 5491;

Peraturan Pemerintah Nomor 24 Tahun 1997 tentang Pendaftaran Tanah, Lembaran Negara Republik Indonesia Tahun 1997 Nomor 59, Tambahan Lembaran Negara Rupblik Indonesia Nomor 3696;

Peraturan Menteri Agraria dan Tata Ruang/Kepala Badan Pertanahan Nasional Republik Indonesia Nomor 2 Tahun 2018 tentang Pembinaan dan Pengawasan Pejabat Pembuat Akta Tanah, Berita Negara Republik Indonesia Tahun 2018 Nomor 395;

Peraturan Kepala Badan Pertanahan Nasional Nomor 1 Tahun 2006 Tentang Ketentuan Pelaksanaan Peraturan Pemerintah Nomor 37 Tahun 
1998 Tentang Peraturan Jabatan Pejabat Pembuat Akta Tanah;

Peraturan Kepala Badan Pertanahan Nasional Nomor 8 Tahun 2012 tentang Perubahan Atas Peraturan Menteri Agraria/Kepala Badan Pertanahan Nasional Nomor 3 Tahun 1997 tentang Ketentuan Pelaksanaan Peraturan Pemerintah Nomor 24 Tahun 1997 tentang Pendaftaran Tanah, Berita Negara Republik Indonesia Tahun 2012 Nomor 439;

Peraturan Bank Indonesia Nomor 14/15/PBI/2012 tentang Penilaian Kualitas Aset Bank Umum, Lembaran Negara Republik Indonesia Tahun 2012 Nomor 202, Tambahan Lembaran Negara Republik Indonesia Nomor 5354;

Kitab Undang - Undang Hukum Perdata. 